\title{
PENERAPAN METODE TREE LENGTH LOGGING SKALA OPERASIONAL DI AREAL TEKNIK SILVIKULTUR INTENSIF (STUDI KASUS DI PT SARMIENTO PARAKANCA TIMBER PROVINSI KALIMANTAN TIMUR)
}

\section{(Application of Tree Length Logging Methods by operational Scale Research in Intensive Silviculture System Area: Case study in PT Sarmiento Parakanca Timber East Kalimantan Province)}

\author{
Maman Mansyur Idris ${ }^{1)}$ \& Soenarno ${ }^{1)}$ \\ ${ }^{1)}$ Pusat Penelitian dan Pengembangan Keteknikan Kehutanan dan Pengolahan Hasil Hutan \\ Jl. Gunung Batu . 5, Bogor. 16610. Telp. (0251)-8633378, Fax. (0251)-8633413 \\ E-mail :maman_mi@yahoo.com \\ Diterima 23 Januari 2014, Disetujui 7 Januari 2015
}

\begin{abstract}
Tree length logging method is an alternative way in timber harvesting to improve the efficiency of timber utilization and preservation of forests resources. This paper studies the performance of tree length logging application method in operational scale. Observation was conducted in the forest area of PT Sarmeinto Parakanca Timber in East Kotawaringin Regency, Central Kalimantan Province, where Intensive Silvicultural Technique (SILIN) was applied. Data were collected through observation and direct measurements in the field including labor productivity and cost of felling and skidding, logging waste, exploitation factor (FE) and the damage of residual stand. Results show both felling productivities and skidding were improved. The felling capacity was improved into $60.535 \mathrm{~m}^{3} /$ hour and skidding was improved into $31.931 \mathrm{~m}^{3} /$ hour. The application of tree length logging can also reduce the felling cost into $\mathrm{R} p 1,604.36 / \mathrm{m}^{3}$ and skidding cost into $\mathrm{R} p 21,142.75 / \mathrm{m}^{3}$. The method also increase the exploitation factors (FE) into 0.93 and minimize the damage on residual stand by $20.70 \%$.
\end{abstract}

Keywords: Tree length logging method, productivity, costs, exploitation factor, residual stand damage

\begin{abstract}
ABSTRAK
Metode tree length logging sebagai alternatif cara pemanenan kayu merupakan upaya untuk meningkatkan efisiensi pemanfaatan hasil hutan kayu dan kelestarian hutan produksi alam. Saat ini kontribusi produksi kayu bulat hutan alam semakin menurun akibat masih borosnya proses pemanenan dan makin terbatasnya luas hutan alam produksi. Penelitian ini bertujuan untuk mengetahui kinerja penerapan metode pembalakan kayu sepanjang mungkin dalam skala operasional. Penelitian dilaksanakan pada areal hutan yang dikelola dengan teknik silvikultur intensif (SILIN) di PT Sarmiento Parakanca Timber (SARPATIM), Kabupaten Kotawaringin Timur, Provinsi Kalimantan Tengah. Pengumpulan data melalui pengamatan dan pengukuran langsung di lapangan meliputi produktivitas kerja dan biaya penebangan dan penyaradan, limbah pembalakan, faktor eksploitasi (FE) dan kerusakan tegakan tinggal. Hasil penelitian menunjukkan bahwa produktivitas penebangan meningkat menjadi $60,535 \mathrm{~m}^{3} / \mathrm{jam}$ dan produktivitas penyaradan sebesar $31,931 \mathrm{~m}^{3} / \mathrm{jam}$. Selain itu, penerapan metode tree length logging dapat memperkecil biaya penebangan menjadi Rp $1.604,36 / \mathrm{m}^{3}$ dan penyaradan $\mathrm{Rp} 21.142,75 / \mathrm{m}^{3}$, meningkatkan nilai FE mejadi 0,93 dan dapat menekan kerusakan tegakan menjadi sebesar 20,70\%.
\end{abstract}

Kata kunci: Metode tree length logging, produktivitas, biaya, faktor eksploitasi, kerusakan tegakan tinggal 


\section{PENDAHULUAN}

Kegiatan pemanenan kayu pada areal hutan dengan teknik silvikultur intensif (SILIN) merupakan prakondisi sebelum kegiatan pembuatan jalur penanaman. Lebar jalur penanaman adalah 3 $\mathrm{m}$ dengan jarak antar jalur satu adalah $20 \mathrm{~m}$ sehingga tersisa areal selebar $\pm 17 \mathrm{~m}$ sebagai jalur konservasi. Kegiatan pembalakan tersebut juga dimaksudkan untuk mengoptimalkan potensi produksi kayu dari sisa tegakan tinggal untuk mendukung pasokan kayu bulat hutan alam yang terus merosot. Produksi kayu bulat hutan alam selama 3 tahun terakhir terus menurun, pada tahun 2011 sebanyak 6,28 juta $\mathrm{m}^{3}$ menjadi 3,67 juta $\mathrm{m}^{3}$ pada tahun 2013 (Kementerian Kehutanan, 2014).

Semakin merosotnya produksi kayu bulat tersebut disebabkan oleh makin menyempitnya luas dan potensi hutan alam serta pelaksanaan pembalakan kayu yang masih menggunakan metode konvensional dengan metode pemotongan batang bebas cabang sepanjang mungkin (cut to length/CTL). Dalam metode CTL ini kegiatan pembagian batang (bucking log) dilakukan di tempat pohon ditebang, serta meninggalkan limbah kayu pada bagian ujung batang bebas cabang yang cukup banyak. Dalam pembalakan terdapat beberapa pilihan metode pembalakan selain CTL, yaitu tree length logging (TL), whole tree logging (WT), dan short wood (SW). Metode WT adalah cara pemanenan kayu terhadap seluruh bagian pohon (batang, cabang dan ranting) kecuali tunggak. Di dunia sebagian besar $(65 \%)$ pembalakan menerapkan metode WT dan $\pm 35 \%$ dilakukan dengan metode TL (Ponsse, 2005). Menurut Idris dkk, (1997) metode W'T lebih tepat diterapkan pada pembalakan dengan sistem tebang habis.

Berbagai penelitian keuntungan dan kerugian metode CTL dibandingkan metode W'T telah banyak dilakukan di luar negeri, khususnya kegiatan pembalakan sistim mekanis di negaranegara Pasifik Timur Laut. Menurut LeDoux and Huyler (2001), kekurangan metode CTL antara lain biaya produksi dan investasi, perbaikan dan perawatan peralatan mesin dan kesulitan melakukan penebangan pohon yang besar $(\varnothing>$ $56 \mathrm{~cm}$ ). Sedangkan kelemahan metode W'T adalah memerlukan banyak tenaga kerja dan pengawas di lapangan (Gingras 1994, LeDoux and Huyler 2001). Bahkan, mempunyai potensi terjadinya kerusakan tanah lebih tinggi akibat manuver traktor yang bergerak ke arah kiri-kanan (sweeping action) sehingga merusak tegakan dan mengelupas lapisan tanah mineral (Hartsough et al. 1997).

Guna mendorong peningkatan produksi kayu bulat, beberapa penelitian metode TL skala uji coba dengan luas petak coba berukuran \pm 1 ha secara random telah dilakukan pada beberapa IUPHHK-HA. Hasil penelitian menunjukkan bahwa secara teknis, ekonomi dan kelestarian cukup prospektif dapat diterapkan pada skala operasional (Idris dan Soenarno, 2012). Atas dasar itu, penelitian metode TL skala operasional ini dilakukan untuk mendapatkan data dan informasi unjuk kerja pembalakan metode tree length logging dalam skala operasional, meliputi aspek produktivitas, biaya, potensi limbah batang bebas cabang dan batang di atas cabang sampai dengan minimal $20 \mathrm{~cm}$, nilai faktor eksploitasi serta tingkat kerusakan tegakan tinggal.

\section{BAHAN DAN METODE}

\section{A. Waktu dan Lokasi Penelitian}

Penelitian dilaksanakan pada bulan Nopember 2013 di areal SILIN PT Sarmiento Parakanca Timber, Kabupaten Kotawaringin Timur, Propinsi Kalimantan Tengah.

\section{B. Bahan dan Alat Penelitian}

Dalam penelitian yang menjadi obyek penelitian adalah sebanyak minimal 300 pohon contoh dari semua jenis komersial yang ditebang di 4 petak tebang terpilih. Bahan yang digunakan dalam penelitian ini adalah cat, kuas dan tali plastik. Sedangkan peralatan yang digunakan adalah pita ukur diameter pohon (phi-band), pengukur sudut kemiringan (helling meter), meteran pita, kompas, tally sheet, parang, chain saw, traktor, alat tulis menulis, perlengkapan lapangan (personal use) dan kamera.

\section{Pengertian}

1. Metode tree length logging adalah cara pemanenan kayu, dimana proses pengeluaran kayu dilakukan secara bersamaan antara batang bebas cabang dengan batang di atas cabang pertama sampai diameter minimum $20 \mathrm{~cm}$. 
2. Penelitian metode tree length logging skala uji coba adalah kegiatan penelitian yang diterapkan di lapangan dalam petak tebang contoh berukuran $100 \times 100 \mathrm{~m}$ (1 ha).

3. Penelitian metode tree length logging skala operasional adalah kegiatan penelitian yang diterapkan di lapangan dalam petak tebang contoh dengan ukuran petak lebih luas, yaitu 10 ha.

\section{Prosedur Penelitian}

Prosedur penelitian dilakukan dengan mengumpulkan data primer dan data sekunder sebagai berikut:

1. Data primer

a. Penentuan petak contoh secara purposif;

b. Pembuatan petak contoh penelitian dengan ukuran $200 \mathrm{~m}$ x $500 \mathrm{~m}$ (10 ha) pada petak tebang rencana kerja tebangan (RKT) tahun 2013;

c. Melakukan reinventarisasi terhadap semua jenis pohon berdiameter 20-39 cm dan jenis pohon berdiameter $\geq 40 \mathrm{~cm}$ dan telah diberi label plastik warna merah;

d. Menebang pohon pada plot penelitian yang telah ditentukan;

e. Mengukur dan mencatat waktu penebangan, diameter dan panjang kayu yang dimanfaatkan dari setiap pohon yang ditebang;

f. Mengukur dan mencatat diameter pangkal dan ujung serta panjang batang kayu yang dimanfaatkan;

g. Mengukur dan mencatat diameter pangkal dan ujung serta panjang limbah pembalakan, baik limbah batang bebas cabang maupun limbah di atas cabang yang berdiameter $\geq 20 \mathrm{~cm}$;

h. Mengukur dan mencatat waktu penyaradan serta panjang jalan sarad mulai dari lokasi pohon ditebang sampai ke tempat pengumpulan kayu sementara;

i. Melakukan pengujian dan pengukuran kayu (grading and scaling) di tempat pengumpulan kayu sementara (TPn) dan seandainya terdapat pemotongan maka diukur diameter pangkal dan ujung serta panjang sortimen kayu yang dipotong;

j. Mengukur kebutuhan bahan bakar minyak (BBM) untuk gergaji rantai dan traktor sarad;

k. Mencatat jumlah tegakan berdiameter minimal $20 \mathrm{~cm}$ yang rusak akibat penebangan dan penyaradan kayu.

2. Data sekunder

Data sekunder yang dikumpulkan antara lain keadaan umum perusahaan, jenis, tipe, tahun pembelian harga gergaji rantai dan traktor sarad yang digunakan, biaya perbaikan dan pemeliharaan alat, harga bahan bakar, harga oli, serta pengalaman kerja operator.

\section{E. Analisis Data}

1. Volume kayu dan faktor eksploitasi

Untuk menghitung volume kayu batang bebas cabang digunakan rumus "Smalian" sebagaimana diuraikan dalam Moeljono (1984):

2. Produktivitas kerja

Produktivitas kerja dihitung menurut prosedur yang diuraikan dalam Mulyadi (2002).

3. Biaya pembalakan

Biaya operasi untuk penebangan dan penyaradan dihitung dengan menggunakan rumus dari FAO (1992).

4. Kerusakan tegakan tinggal

Untuk menghitung persentase kerusakan tegakan tinggal yang terjadi dapat dihitung dengan menggunakan rumus yang diuraikan dalam Jalal (2013).

\section{HASIL DAN PEMBAHASAN}

\section{A. Penebangan}

Penebangan hanya dilakukan terhadap semua jenis pohon komersial berdiameter $\geq 40 \mathrm{~cm}$ yang telah dipasang nomor pohon dengan plastik warna merah. Kegiatan penebangan yang meliputi pembagian batang (bucking), pemotongan cabang (branching) dan pemotongan bagian ujung (topping) dilakukan di petak tebang. Tabel 1 menunjukkan bahwa produktivitas penebangan berkisar antara $17,679-150,897 \mathrm{~m}^{3} /$ jam dengan rata-rata 60,535 $\mathrm{m}^{3} /$ jam. Keragaman produktivitas penebangan yang cukup besar mungkin dipengaruhi oleh diameter pohon yang ditebang juga dapat disebabkan oleh perbedaan jenis pohon serta porsi limbah kayu di atas batang bebas cabang. Pada pohon jenis terapung (floater) umumnya waktu penebangan lebih cepat dibandingkan jenis yang tenggelam (sinker) demikian juga bila pohon 
yang ditebang terdapat potensi limbah diatas cabang maka waktu penebangan cenderung lebih lama. Bentuk dan ukuran tinggi banir pohon dapat memperlambat waktu penyelesaian penebangan. Pada pohon yang tidak berbanir atau berbanir dengan bentuk tunggal dan tidak terlalu tinggi maka waktu penebangan relatif lebih cepat. Hal terpenting dalam kaitannya antara bentuk dan ukuran tinggi banir adalah tingkat kesulitan pembuatan takik rebah maupun takik balas.

Tabel 1. Produktivitas penebangan pada metode tree length logging di areal SILIN Table 1. Tree felling productivity of the tree length logging on SILIN area

\begin{tabular}{cccccc}
\hline No. & Uraian (Description) $)$ & $\begin{array}{c}\text { Diameter } \\
\text { pohon } \\
\text { (Tree diametre })\end{array}$ & $\begin{array}{c}\text { Kayu } \\
\text { dimanfatkan } \\
(\text { Utilized wood })\end{array}$ & $\begin{array}{c}\text { Waktu tebang } \\
(\text { Felling time })\end{array}$ & $\begin{array}{c}\text { Produktivitas } \\
\text { (Productivity) }\end{array}$ \\
\cline { 3 - 6 } & $(\mathrm{cm})$ & $\begin{array}{c}\left(\mathrm{m}^{3} / \text { pohon, }\right. \\
\left.\mathrm{m}^{3} / \text { tree }\right)\end{array}$ & (menit, minutes $)$ & $\left(\mathrm{m}^{3} /\right.$ jam, $\mathrm{m}^{3} /$ hour $)$ \\
\hline 1 & Rata-rata (Average) & 68 & 6,260 & 6,5 & 60,535 \\
2 & Terkecil (Minimum) & 40 & 1,320 & 2,1 & 17,679 \\
3 & Terbesar (Maximum $)$ & 134 & 28,373 & 27,1 & 150,897 \\
4 & $\begin{array}{l}\text { Simpangan baku } \\
\text { (Standard deviation) }\end{array}$ & 19 & 5,223 & 4,89 & 24,333 \\
\hline
\end{tabular}

Tabel 2. Biaya penebangan pada tree length logging di areal SILIN Table 2. Felling cost of the tree length logging on SILIN area

\begin{tabular}{|c|c|c|c|}
\hline No & Uraian (Discriptions) & & Keterangan (Remarks) \\
\hline A. & $\begin{array}{l}\text { Komponen biaya alat, } \mathrm{Rp} / \mathrm{jam} \text { (Cost } \\
\text { element, Rp/hour) }\end{array}$ & & \\
\hline 1 & Penyusutan alat (Depreciation) & $4.200,00$ & \\
\hline 2 & Bunga asuransi (Insurance) & 42,00 & \\
\hline 3 & Bunga bank (Bank interest) & $2.100,00$ & \\
\hline 4 & Pajak (Tax) & 280,00 & \\
\hline 5 & Bahan bakar (Gasoline) & $18.998,17$ & Rp 12,.000/liter \\
\hline 6 & Oli dan pelumas (Oil and grase) & $1.8,99,82$ & \\
\hline 7 & Upah operator (Operator's wage) & $67.500,00$ & $\begin{array}{l}\text { Penebang dan pembantu } \\
\text { (Chain saw operator and helper) }\end{array}$ \\
\hline 8 & $\begin{array}{l}\text { Perbaikan dan pemeliharaan } \\
\text { (repair and maintenance) }\end{array}$ & $2.100,00$ & \\
\hline & Jumlah (Total) & $97.119,99$ & \\
\hline B. & $\begin{array}{l}\text { Produktivitas, } \mathrm{m}^{3} / \text { jam (Productivity, } \\
m^{3} / \text { hour) }\end{array}$ & 60,535 & \\
\hline C. & $\begin{array}{l}\text { Biaya penebangan, } \mathrm{Rp} / \mathrm{m}^{3} \text { (Felling cost, } \\
\mathrm{R} p / \mathrm{m}^{3} \text { ) }\end{array}$ & $1.604,36$ & \\
\hline
\end{tabular}


Alat yang digunakan dalam penebangan pohon adalah gergaji mesin (chain saw) STIHL MS070 berkekuatan mesin 6,5 HP buatan tahun 2010 . Harga gergaji mesin tersebut adalah $\mathrm{Rp}$ 14.000.000 dengan umur pakai selama 3 tahun atau 3.000 jam. Menurut pengalaman penebang setiap 3 bulan harus diganti rantai yang berharga Rp 300.000 diganti "bar" sebagai tempat rantai berputar setiap 1 tahun dengan harga Rp 900.000. Selama penelitian dilakukan pada petak contoh seluas 10 ha dan jumlah pohon ditebang sebanyak 54 pohon, diperlukan waktu kerja efektif 350,6 menit atau 5,8 jam dengan total kebutuhan BBM sebanyak 9,25 liter. Kebutuhan bahan pelumas (oli) adalah $\pm 10 \%$ dari BBM. Berdasarkan data produktivitas penebangan (Tabel 1) dan informasi tersebut di atas, maka dapat dihitung biaya penebangan seperti disajikan pada Tabel 2 .

\section{B. Penyaradan Metode Tree Length Logging}

Hasil pengukuran waktu kerja dan perhitungan produktivitas penyaradan dapat dilihat pada Lampiran 1, sedangkan rekapitulasinya disajikan pada Tabel 3 .

Tabel 3 tampak bahwa produktivitas penyaradan metode tree length logging berkisar antara 4,558 - 143,671 $\mathrm{m}^{3} /$ jam dengan rata-rata $31,931 \mathrm{~m}^{3} / \mathrm{jam}$. Produktivitas penyaradan skala operasional tersebut lebih baik dibandingkan dengan skala penelitian uji coba di IUPHHK-HA yang hanya $15,520 \mathrm{~m}^{3} / \mathrm{jam}$ (Idris dan Soenarno, 2012).

Alat yang digunakan untuk penyaradan kayu metode tree length adalah traktor Komatzu D85SS tahun pembuatan 2008 dengan harga sebesar Rp 2.500.000.000. Umur pakai alat tersebut 5 tahun $(10.000 \mathrm{jam})$ atau $\pm 2.000 \mathrm{jam} /$ tahun dan daya sebesar 220 HP. Diasumsikan biaya asuransi adalah 3\%/tahun, bunga bank 15\%/tahun, pajak $2 \% /$ tahun, upah operator traktor Rp 300.000/hari atau Rp 37.500/jam dan pembantu sebesar Rp 30.000/jam (80\% upah operator traktor). Selama penelitian dilakukan pada petak contoh seluas 10 ha dan jumlah pohon ditebang sebanyak 54 pohon, diperlukan waktu kerja efektif 350,6 menit atau 5,8 jam dengan total kebutuhan BBM sebanyak $\pm 352,5$ liter solar. Kebutuhan bahan pelumas (oli) adalah $\pm 10 \%$ dari BBM. Berdasarkan data produktivitas penebangan (Tabel 3) dan informasi tersebut diatas, maka dapat dihitung opersional penebangan seperti disajikan pada Tabel 4.

Tabel 4 menunjukkan bahwa biaya penyaradan kayu adalah sebesar Rp 675.109,19/jam atau sebesar Rp 21.142,75/ $\mathrm{m}^{3}$ pada jarak sarad ratarata $195 \mathrm{~m}$. Biaya penyaradan skala operasional tersebut lebih murah dibandingkan dengan skala penelitian, yaitu $\mathrm{Rp} 34.156,70 / \mathrm{m}^{3}$ pada jarak sarad rata-rata $195 \mathrm{~m}$ (Idris dan Soenarno, 2012). Perbedaan tersebut diduga lebih disebabkan oleh besarnya perbedaan daya traktor, ukuran luas plot penelitian dan kondisi topografi lapangan dibandingkan dengan volume kayu dan jarak sarad (lihat Tabel 5). Pada petak tebang yang lebih luas maka proses penyaradan lebih efektif karena traktor tidak selalu membuat jalur jalan sarad yang baru dan manuver traktor lebih mudah.

Tabel 3. Produktivitas penyaradan kayu metode tree length logging Tabel 3. Skidding productivity of the tree length logging method

\begin{tabular}{clcccc}
\hline No. & Uraian (Description) & $\begin{array}{c}\text { Kayu } \\
\text { dimanfaatkan } \\
(\text { Utilized wood }) \\
\left(\mathrm{m}^{3} / \text { pohon, }\right. \\
\left.\mathrm{m}^{3} / \text { tree }\right)\end{array}$ & $\begin{array}{c}\text { Jarak sarad } \\
\text { (Skidding } \\
\text { distance }) \\
(\mathrm{m})\end{array}$ & $\begin{array}{c}\text { Waktu } \\
\text { penyaradan } \\
\text { (Skidding time }) \\
(\text { menit, Minutes })\end{array}$ & $\begin{array}{c}\text { Produktivitas } \\
\text { penyaradan } \\
\text { (Skidding productivity) } \\
\left(\mathrm{m}^{3} / \text { jam, } \mathrm{m}^{3} . \text { hm } / \text { hour }\right)\end{array}$ \\
\hline 1 & Rata-rata (Average $)$ & 6,260 & 195 & 13,95 & 31,931 \\
2 & Terkecil (Minimum) & 1,320 & 40 & 3,55 & 4,558 \\
3 & $\begin{array}{l}\text { Terbesar } \\
\text { (Maximum) }\end{array}$ & 28,373 & 370 & 41,39 & 143,671 \\
4 & $\begin{array}{l}\text { Simpangan baku } \\
\text { (Standard deviation })\end{array}$ & 5,223 & 92 & 6,65 & 28,830 \\
\hline
\end{tabular}


Tabel 4. Biaya penyaradan metode tree length logging dengan traktor Komatzu D85SS Table 4. Skidding cost of the tree length logging method using Komatzu tractor D85SS

\begin{tabular}{|c|c|c|c|}
\hline No & Uraian (Discriptions) & & Keterangan (Remarks) \\
\hline A. & $\begin{array}{l}\text { Komponen biaya alat, Rp/jam (Cost } \\
\text { elemen, Rp/ hour) }\end{array}$ & & \\
\hline 1 & Penyusutan alat (Depreciation) & $225.000,00$ & \\
\hline 2 & Bunga asuransi (Insurance) & $2.250,00$ & \\
\hline 3 & Bunga bank (Bank interest) & $112.500,00$ & \\
\hline 4 & Pajak (Tax) & $15.000,00$ & \\
\hline 5 & Bahan bakar (Gasoline) & $212.500,00$ & $\begin{array}{l}\text { Harga solar (Price of diesel fuel), } \\
\text { Rp 8,500/liter }\end{array}$ \\
\hline 6 & Oli dan pelumas (Oil and grease) & $21.250,00$ & \\
\hline 7 & Upah operator (Operator's wage) & $67.500,00$ & $\begin{array}{l}\text { Operator traktor dan pembantu (Operator } \\
\text { tractor and hockman) }\end{array}$ \\
\hline 8 & $\begin{array}{l}\text { Perbaikan dan pemeliharaan (repair and } \\
\text { maintenance) }\end{array}$ & $19.109,19$ & \\
\hline & Jumlah (Total) & $675.109,19$ & \\
\hline B. & Produktivitas $\left(\mathrm{m}^{3} / \mathrm{jam}\right)$ & 31,931 & \\
\hline C. & $\begin{array}{l}\text { Jarak sarad rata-rata (Average of skidding } \\
\text { distance), } \mathrm{m}\end{array}$ & 195 & \\
\hline $\mathrm{D}$. & Biaya penyaradan $($ Skidding cost $)\left(\mathrm{Rp} / \mathrm{m}^{3}\right)$ & $21.142,75$ & \\
\hline
\end{tabular}

Tabel 5. Perbandingan umum kondisi penelitian skala uji coba dan skala operasional pada areal SILIN

Table 5. General comparison condition between trial and operasional research in SILIN area

\begin{tabular}{|c|c|c|c|}
\hline \multirow{2}{*}{ No. } & \multirow{2}{*}{ Uraian (Description) } & \multicolumn{2}{|c|}{ Skala penelitian (Scale of research) } \\
\hline & & Uji coba (Trial)*) & Operasional (Operational) \\
\hline 1. & Luas petak penelitian (Reasearch plots) & 4ha@1 ha & 10 ha (solid) \\
\hline 2. & $\begin{array}{l}\text { Tipe traktor sarad, tahun pembelian } \\
\text { (Skidder type, year of purchase) }\end{array}$ & Catterpilar D7G , 2004 & Komatzu D85SS, 2009 \\
\hline 3. & Daya traktor (Power of skidder), HP & 180 & 220 \\
\hline 4. & Topografi lapangan (Topography) & Datar (Flat)-curam (Steep) & Datar (Flat) \\
\hline 5. & $\begin{array}{l}\text { Rata-rata } \mathrm{p} \text { anjang jalan sarad (Average of } \\
\text { skidding distance), } \mathrm{m}\end{array}$ & 152 & 195 \\
\hline 6. & $\begin{array}{l}\text { Rata-rata diameter pohon (Average of tree } \\
\text { diameters), } \mathrm{cm}\end{array}$ & 71 & 68 \\
\hline 7. & Volume kayu yang disarad ( $\mathrm{m}^{3} /$ pohon) & 4,894 & 6,259 \\
\hline 8. & $\begin{array}{l}\text { Waktu penyaradan, jam (Time of skidding, } \\
\text { hour) }\end{array}$ & 0,27 & 0,11 \\
\hline
\end{tabular}

Keterangan (Remark) : *) Sumber (Source), Idris dan Soenarno (2012): Data diolah sesuai keperluan (Data processed as required) 
Hasil pengamatan di lapangan terhadap proses penyaradan kayu menunjukkan bahwa secara teknis operator traktor sebenarnya telah berupaya melaksanakan kaidah-kaidah pembalakan berdampak rendah (reduced impact logging/RIL), yaitu dengan melakukan teknik penarikan kayu menggunakan kabel sling (winching). Namun demikian, ketrampilan mereka perlu ditingkatkan karena kesalahan hal teknis masih ditemukan di lapangan, misalnya :

1. Operator traktor tidak perlu melakukan teknik winching padahal kondisi kayu berada pada jalan sarad relatif datar dan tidak berkelok.

2. Setelah proses winching, posisi ujung kayu yang diikat tidak bersandar pada body/kedudukan winch sehingga kayu yang disarad berjalan di atas tanah (ground skidding). Kondisi ini harus dihindari karena mengakibatkan tanah terkelupas, kayu menjadi sangat kotor, sebagian label pohon ditebang hilang/tertutup lumpur sehingga sulit dikenali setelah sampai di Tpn.

3. Kurang cermat melakukan orientasi posisi pohon ditebang bahkan kadang menyarad pohon ditebang yang belum dilakukan pemotongan cabang (branching) dan pemotongan bagian ujung pohon (topping).

\section{Limbah Pembalakan dan Faktor Eksploitasi (FE)}

Hasil pengukuran limbah pembalakan dan perhitungan FE operasional dan uji coba dapat dilihat pada Lampiran 1 dan Lampiran 2. Rekapitulasi hasil perhitungan nilai FE rata-rata disajikan pada Tabel 6 .

Tabel 6. Rata-rata volume limbah batang bebas cabang (BBC) dan FE metode tree length logging di PT SARPATIM.

Table 6. Averages waste of clearbole wood and exploitation factor of tree length logging metode in PT SARPATIM

\begin{tabular}{|c|c|c|c|c|c|c|}
\hline \multirow[b]{2}{*}{ No. } & \multirow[b]{2}{*}{ Uraian (Description) } & \multicolumn{3}{|c|}{ Volume, $\mathrm{m}^{3} /$ pohon $\left(\mathrm{m}^{3} /\right.$ tree $)$} & \multirow[b]{2}{*}{$\begin{array}{c}\text { Faktor } \\
\text { eksploitasi } \\
(\text { Exploitation } \\
\left.\text { (factor })^{*}\right)\end{array}$} & \multirow[b]{2}{*}{$\begin{array}{c}\text { Faktor } \\
\text { eksploitasi } \\
(\text { Exploitation } \\
\left.\text { factor })^{* *}\right)\end{array}$} \\
\hline & & $\begin{array}{c}\text { Kayu } \\
\text { dimanfaatkan } \\
\text { (Utilized wood) }\end{array}$ & $\begin{array}{l}\text { Limbah } \\
\text { BBC } \\
\text { (Clearbole } \\
\text { waste) }\end{array}$ & $\begin{array}{c}\text { Total BBC } \\
\text { (Total of } \\
\text { clear bole } \\
\text { wood) }\end{array}$ & & \\
\hline 1 & Rata-rata (Average) & 6,260 & 0,521 & 6,781 & 0,93 & 0.90 \\
\hline 2 & Terkecil (Minimum) & 1,320 & 0,002 & 1,453 & 0,79 & 0.05 \\
\hline 3 & $\begin{array}{l}\text { Terbesar } \\
\text { (Maximum) }\end{array}$ & 28,373 & 2,612 & 30,985 & 1,00 & 0.78 \\
\hline 4 & $\begin{array}{l}\text { Simpangan baku } \\
\text { (Standard deviation) }\end{array}$ & 5,223 & 0,66 & 5,753 & 0,06 & 0.95 \\
\hline
\end{tabular}

Keterangan (Remarks) : *) Skala penelitian operasional (Operational research scale), **) Skala penelitian uji coba (Trial research scale)

Tabel 6 menunjukkan bahwa volume limbah BBC berkisar antara $0,002-2,612 \mathrm{~m}^{3} /$ pohon $(0-$ $20,66 \%)$ dengan rata-rata $0,521 \mathrm{~m}^{3} /$ pohon $(6,93 \%)$ atau lebih sedikit dibadingkan hasil uji coba sebanyak $1,542 \mathrm{~m}^{3} /$ pohon atau $8,91 \%$ (Idris MM dan Soenarno, 2012). Hal tersebut lebih diakibatkan oleh perbedaan diameter pohon yang ditebang dan kondisi topografi lapangan. Diameter pohon pada skala uji coba adalah $71 \mathrm{~cm}$ (Idris dan Soenarno, 2012) sedangkan pada penelitian skala operasional $68 \mathrm{~cm}$. Sedangkan topografi lapangan pada skala operasional arealnya relatif datar tetapi di petak contoh skala uji coba bervariasi dari datar hingga curam.

Besarnya limbah pembalakan sangat dipengaruhi oleh faktor penebangan dibandingan penyaradan. Ketrampilan penebang khususnya dalam pembuatan takik rebah maupun takik balas berpengaruh terhadap ketepatan arah rebah pohon dan terjadinya kerusakan kayu. Pengamatan di lapangan menunjukkan bahwa kebiasaan operator gergaji rantai masih membuat 
takik rebah terlalu dangkal $(1 / 5-1 / 3$ diameter pohon), mulut takik rebah terlalu kecil $\left(<45^{\circ}\right)$, takik balas dibuat terlalu jauh dari tinggi dasar takik sehingga mengakibatkan terjadinya kayu engsel yang tinggi. Bahkan pada pohon berbanir tinggi tidak dilakukan pembuangan banir pohon sebelum penebangan karena alasan produksi yang tidak memenuhi standar grading. Akibatnya, sebagian menimbulkan pecah kayu pada batang bebas cabang maupun kayu di atas batang bebas cabang sehingga bisa memperkecil nilai faktor eksploitasi (FE). Dengan demikian jatah produksi tebangan (JPT) sukar dicapai.

Tabel 6 menunjukkan bahwa nilai FE pada skala operasional penelitian berkisar antara 0,79 1,00 atau rata-rata 0,93 lebih tinggi dibandingkan skala uji coba, yaitu berkisaran antara 0,66-1,00 dengan rata-rata 0,90 (Idris dan Soenarno, 2012). Untuk menguji nilai $\mathrm{FE}$ hasil penelitian skala operasional dengan penelitian uji coba dilakukan analisis menggunakan PWSTAT versi. 18 dengan hipotesis bahwa $\mathrm{H}_{\mathrm{o}}: \mu=0,90$ lawan $\mathrm{H}_{1} \mu \neq 0,90$ dengan selang kepercayaan $99 \%$, se-bagaimana disajikan pada Tabel 7. Hasil pengujian pada Tabel 7 menunjukkan bahwa perbedaan nyata antara nilai FE skala uji coba dan skala operasi-onal, sehingga dapat disimpulkan bahwa nilai FE pada penelitian skala operasional lebih baik di-bandingkan nilai FE pada saat penelitian uji coba.

Saat ini nilai FE yang ditetapkan Kementerian Kehutanan untuk menghitung JPT kayu bulat di IUPHHK-HA masih sebesar 0,70. Apabila penyaradan sistem tree length logging diterapkan maka akan ada peningkatan nilai faktor eksploitasi tersebut. Hasil penelitian ini dapat meningkatkan faktor eksploitasi sebesar 0,22 atau peningkatan efisiensi pemanfaatan kayu sebanyak $23 \%$. Peningkatan nilai faktor eksploitasi ini dikarenakan pada penerapan sistem tree length penyaradan dilakukan sepanjang mungkin sesuai kemampuan traktor. Dengan demikian batang bebas cabang dan batang diatas cabang disarad ke TPn, sehingga kayu dari batang bebas cabang semuanya dapat dimanfaatkan, kecuali bagian pangkal ditinggalkan karena pecah, gerowong atau busuk. Kecenderungan terjadinya peningkatan nilai faktor eksploitasi tersebut juga menambah optimisme bahwa sebagian defisit kebutuhan kayu akan dapat dipenuhi dari peningkatan produksi kayu bulat hutan alam.

Hasil pengukuran limbah batang di atas cabang (BAC) dengan metode tree length logging dapat dilihat pada Lampiran 1, sedangkan rekapitulasi hasil limbah rata-rata disajikan pada Tabel 8.

Tabel 8 menggambarkan bahwa potensi limbah batang di atas cabang (BAC) berkisar antara $0,00-1,020 \mathrm{~m}^{3} /$ pohon dengan rata-rata $0,182 \mathrm{~m}^{3} /$ pohon atau sebesar rata-rata $2,68 \%$ terhadap total volume BBC. Potensi limbah BAC tersebut lebih besar bila dibandingkan dengan volume limbah BBC pada skala uji coba penelitian, yaitu berkisar antara 0,230-1,200 $\mathrm{m}^{3} /$ pohon dengan rata-rata sebesar 0,610 $\mathrm{m}^{3} /$ pohon atau sebesar $10,15 \%$ (Idris MM dan Soenarno, 2012). Dilihat dari potensi limbah tersebut sebaiknya dapat dimanfaatkan untuk diolah lebih lanjut baik menjadi kayu gergajian, venir atau kayu serpih sehingga meningkatkan nilai tambah. Dalam peraturan Menetri Kehutanan nomor P.9/Menhut-II/2009 jo peraturan Menteri Kehutanan nomor P.35/Menhut-II/2008 pemegang IUPHHK-HA dapat membangun industri pengolahan kayu primer di dalam kawasan, antara lain portable band saw, portable circular saw, portable rotary peeler, portable slicerdan atau portable chipper.

Tabel 7. Analisis sidik ragam pada nilai faktor eksploitasi

\section{Table 7. Analysis of variance (ANOVA) on exploitation factor}

\begin{tabular}{|c|c|c|c|c|c|c|}
\hline & \multicolumn{6}{|c|}{ Nilai uji (Test Value $)=0.90$} \\
\hline & \multirow{2}{*}{$\mathrm{t}$} & \multirow{2}{*}{$\begin{array}{l}\text { Derajat } \\
\text { bebas } \\
\text { (Degree of } \\
\text { freedom) }\end{array}$} & \multirow{2}{*}{$\begin{array}{c}\text { Probabilitas pengujian } \\
\text { dua pihak (Significance } \\
\text { 2-tailed) }\end{array}$} & \multirow{2}{*}{$\begin{array}{l}\text { Beda rata-rata } \\
\text { (Mean difference) }\end{array}$} & \multicolumn{2}{|c|}{$\begin{array}{l}99 \% \text { Selang kepercayaan (Confidence } \\
\text { Interval of the difference) }\end{array}$} \\
\hline & & & & & $\begin{array}{l}\text { Batas bawah } \\
\text { (Lower) }\end{array}$ & $\begin{array}{l}\text { Batas atas } \\
\text { (Upper) }\end{array}$ \\
\hline $\mathrm{FE}$ & 3,755 & 52 & 0,000 & 0,03019 & 0,0087 & 0,0517 \\
\hline
\end{tabular}




\section{Kerusakan Tegakan Tinggal}

Kerusakan tegakan akibat penebangan dan penyaradan sangat sulit untuk dihindarkan. Hasil pengamatan kerusakan tegakan tinggal pada areal SILIN menggunakan metode tree length logging skala oparasional dan skala uji coba dapat dilihat pada Lampiran 1. Dari Lampiran 1 diketahui bahwa jumlah pohon ditebang rata-rata 54 pohon dan yang rusak akibat pembalakan 29 pohon. Hasil inventarisasi yang dilakukan, dalam petak contoh seluas 10 ha terdapat 242 pohon $( \pm 24$ pohon/ha) yang terdiri dari 177 pohon berdiameter antara $20-39 \mathrm{~cm}$ dan 65 pohon berdiameter $40 \mathrm{~cm}$ keatas. Berdasarkan data tersebut, maka besarnya tingkat kerusakan tegakan tinggal adalah 15,43\%, dimana 5,86\% akibat penebangan dan $9,59 \%$ akibat penyaradan. Tingkat kerusakan tegakan tinggal tersebut lebih rendah dibandingkan hasil yang diperoleh dari skala penelitian sebesar 24,58\% (Idris dan Soenarno, 2012). Hasil penelitian Muhdi (2009) dan Limbeck-Lilienau (2003) menyebutkan bahwa kerusakan tegakan tinggal akibat pembalakan adalah sebesar $18,80 \%$ dan $16 \%$.

Perbedaan tingkat kerusakan tegakan tinggal tersebut disebabkan karena kerapatan tegakan di areal penelitian skala operasional $( \pm 24$ pohon/ha) lebih sedikit dibandingkan yang terdapat di areal dengan skala uji coba $( \pm 30$ pohon/ha). Dalam operasi pembalakan, baik penebangan maupun penyaradan resiko jumlah pohon yang rusak makin besar dengan makin meningkatnya kerapatan tegakan. Namun demikian, tidak dipungkiri bahwa faktor ketrampilan penebang, operator traktor dan kondisi topografi juga turut berperan sedikit atau banyaknya kerusakan yang ditimbulkan selama oeprasi pembalakan. Menurut Siapno (1970) tegakan tinggal dinilai cukup baik apabila pada tegakan tinggal tersebut terdapat pohon yang sehat 41-59\%. Apabila dikaitkan dengan persyaratan tersebut maka kerusakan tegakan tinggal yang dengan metode tree length logging masih dinilai baik sehingga tidak mengkhawatirkan keberlanjutan dan kelestarian produksi pada siklus tebang selanjutnya.

\section{KESIMPULAN DAN SARAN}

\section{A. Kesimpulan}

Produktivitas rata-rata penyaradan metode tree length logging pada skala operasional adalah 31,931 $\mathrm{m}^{3} /$ jam lebih tinggi dibandingkan dengan skala uji coba yang hanya $15,520 \mathrm{~m}^{3} / \mathrm{jam}$. Biaya rata-rata penyaradan kayu metode tree length logging pada skala operasional sebesar Rp 21.142,75/ $\mathrm{m}^{3}$ lebih murah dibandingkan dengan skala uji coba yang mencapai Rp 34.156,70/ $\mathrm{m}^{3}$.

Dari aspek pemanfaatan kayu, penerapan metode tree length logging skala operasional lebih efisien ( $\mathrm{FE}=0,93)$ dibandingkan skala uji coba sebesar 0,90 .

Penerapan metode tree length logging skala operasional memiliki nilai kerusakan tegakan sebesar 15,43\% lebih rendah dibandingkan skala uji coba yang mencapai $24,58 \%$

\section{B. Saran}

Untuk meningkatkan efisensi pemanfaatan kayu hutan alam yang berasaskan pada prinsip kelestarian sangat disarankan PT SARPATIM dapat menerapkan metode tree length logging.

Guna meningkatkan nilai tambah sebaiknya PT SARPATIM tidak saja mengolah limbah kayu yang berasal dari batang bebas cabang saja, akan tetapi juga yang berasal dari batang di atas cabang.

\section{DAFTAR PUSTAKA}

FAO. (1992). Cost control in forest harvesting \& road contruction. FAO forestry paper no 99, Rome: FAO of the UN.

Gingras, JF. (1996). The cost of product sorting during harvesting. Wood Harvesting Tech. TN-245. Forest Eng. Institute of Canada, PointeClaire, Quebec, Canada. 12 pp.

Hartsough, BR., Drews ES, McNell JF. Durston TA \& Stokes, BJ. (1997). Comparison of mechanized systems for thinning ponderosa pine and mixed conifer stands. For. Prod.J, 47(11/12), 59-68. 
Idris MM, Endom W \& Sukanda. (1997). Estimasi dampak intensifikasi pembalakan terhadap tegakan tinggal di daerah kerja HPH. Studi kasus di areal kerja konsesi hutan PT NKR, Muara Wahau, Propinsi Kalimantan Timur. Laporan Proyek. Bogor: Pusat Penelitian dan Pengembangan Keteknikan Kehutanan dan Pengolahan Hasil Hutan. Tidak dipublikasikan.

\& Soenarno. (2012). Teknik tree length logging di hutan produksi lahan kering. Laporan Hasil Penelitian. Bogor: Pusat Penelitian dan Pengembangan Keteknikan Kehutanan dan Pengolahan Hasil Hutan. Tidak dipublikasikan.

Jalal, PS. (2013). Residual stand damages after decreasing on selective cutting diameter limit at forest concession of PT Tri Tunggal Ebony cooperation Poso District Sulawesi Province. Jurnal of Natural Sciences Research. $3(7)$.

Kementerian Kehutanan. (2014). Statistik Kehutanan Indonesia 2013. Jakarta: Kementerian Kehutanan.

LeDoux, CB \& Huyler NK. (2001). Comparison of two cut-to-length harvesting systems operating in eastern hardwoods. Inter. Jurnal of Forest Engineering. 12 (1):53-59.
Limbeck-Lilienau, B. (2003). Residual stand damage caused by mechanized harvesting systems. Proceedings of the Austro 2003 meeting: High Tech Forest Operations for Mountainous Terrain. CD ROM. LimbeckLilienau, Steinmüller and Stampfer (editors). October 5-9, 2003, Schlaegl Austria. $11 \mathrm{p}$.

Muhdi. (2009). Dampak pemanenan kayu dengan teknik reduced impact logging terhadap kerusakan tegakan sisa di hutan alam. Berk. Penelitian Hayati 15 (77-84).

Mulyadi, A. (2002). Analisis produktivitas kerja dan biaya pemanenan hasil hutan di hutan rakyat. Jurnal Hutan Rakyat IV (1).

Moeljono, SB. (1984). Pengantar Pembalakan. Semarang: Penerbit Yayasan Kanisius. Cetakan keempat.

Pulkki, R. (1999). Cut-to length, tree length or whole tree length harvesting. Lakehead University. Faculty of Forestry.

Ponsse O. (2005). The cut-to-length harvesting system. wmw.ponsse.com. Accessed November 27, 2005.

Siapno, IB. (1970). Guide for tree injury study. Handbook of Selective Logging, Second Edition. Manila, Phillippines. 


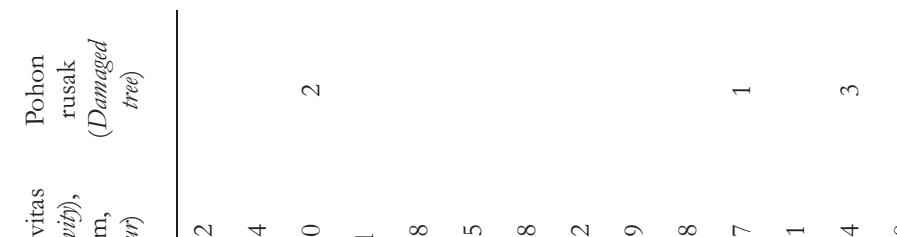

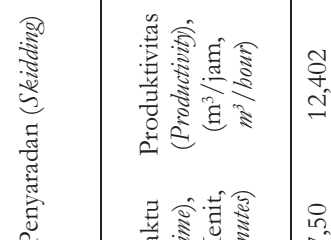

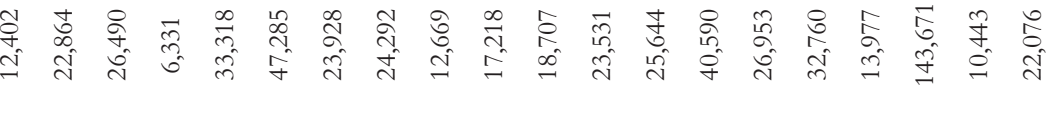

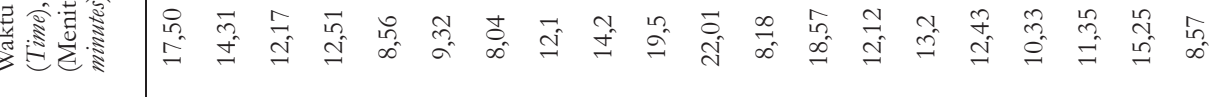

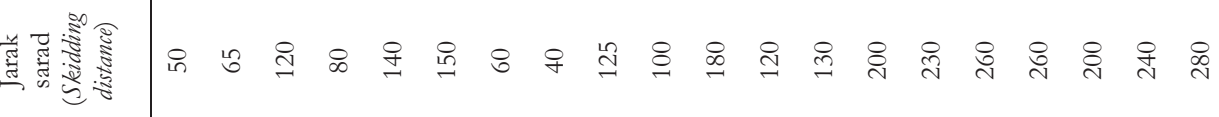

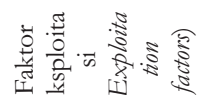

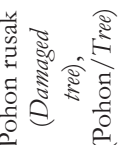

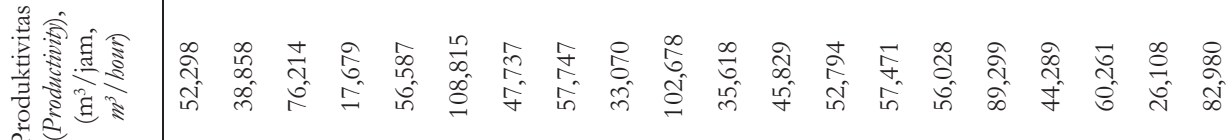

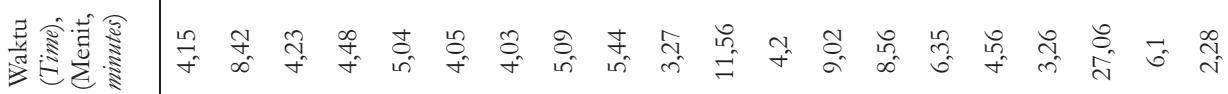

曐

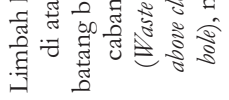

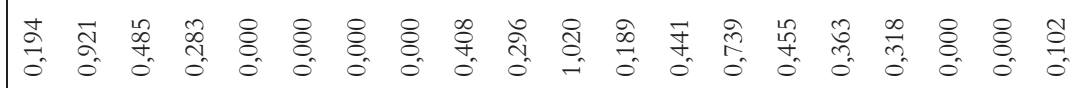




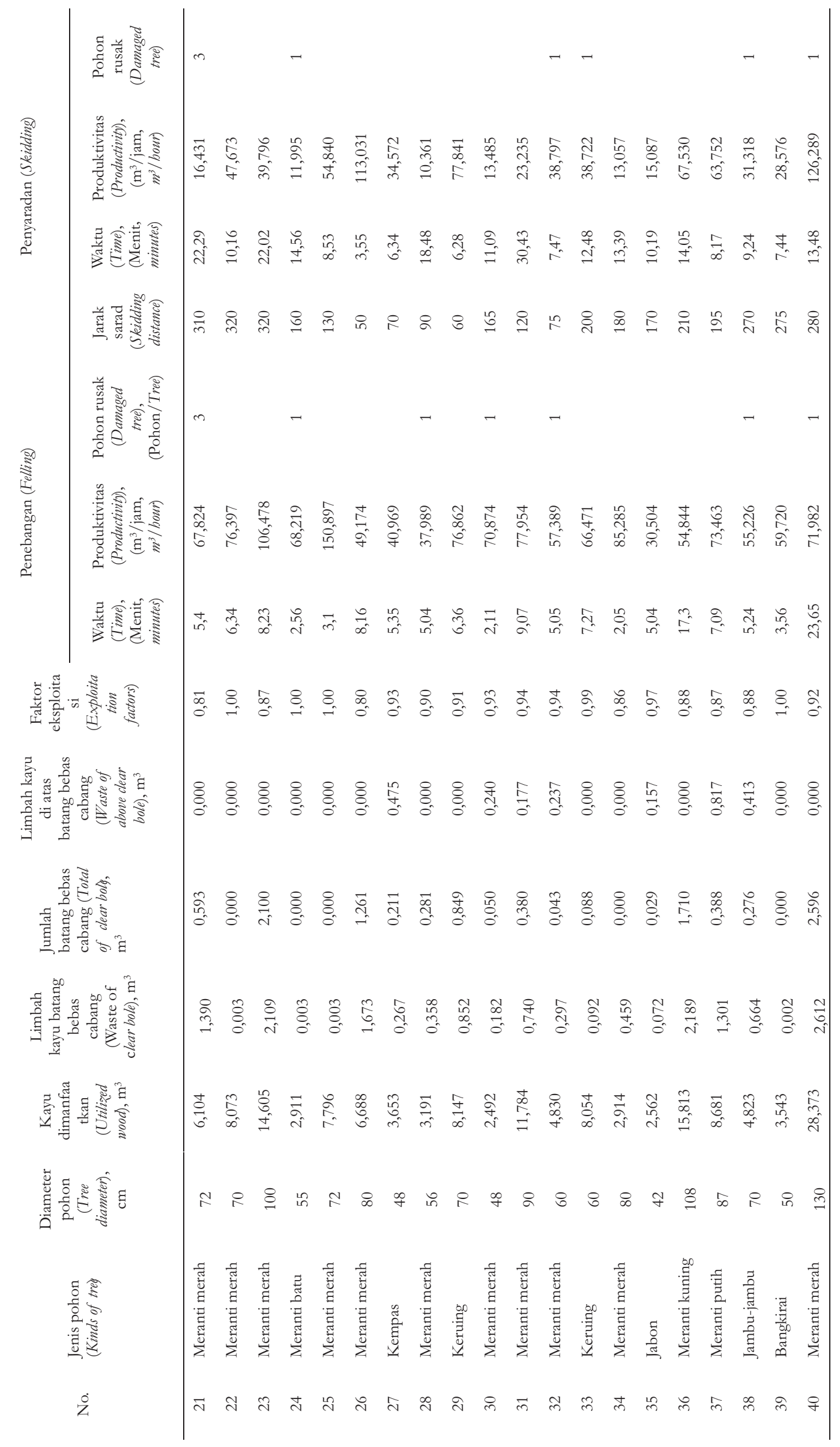




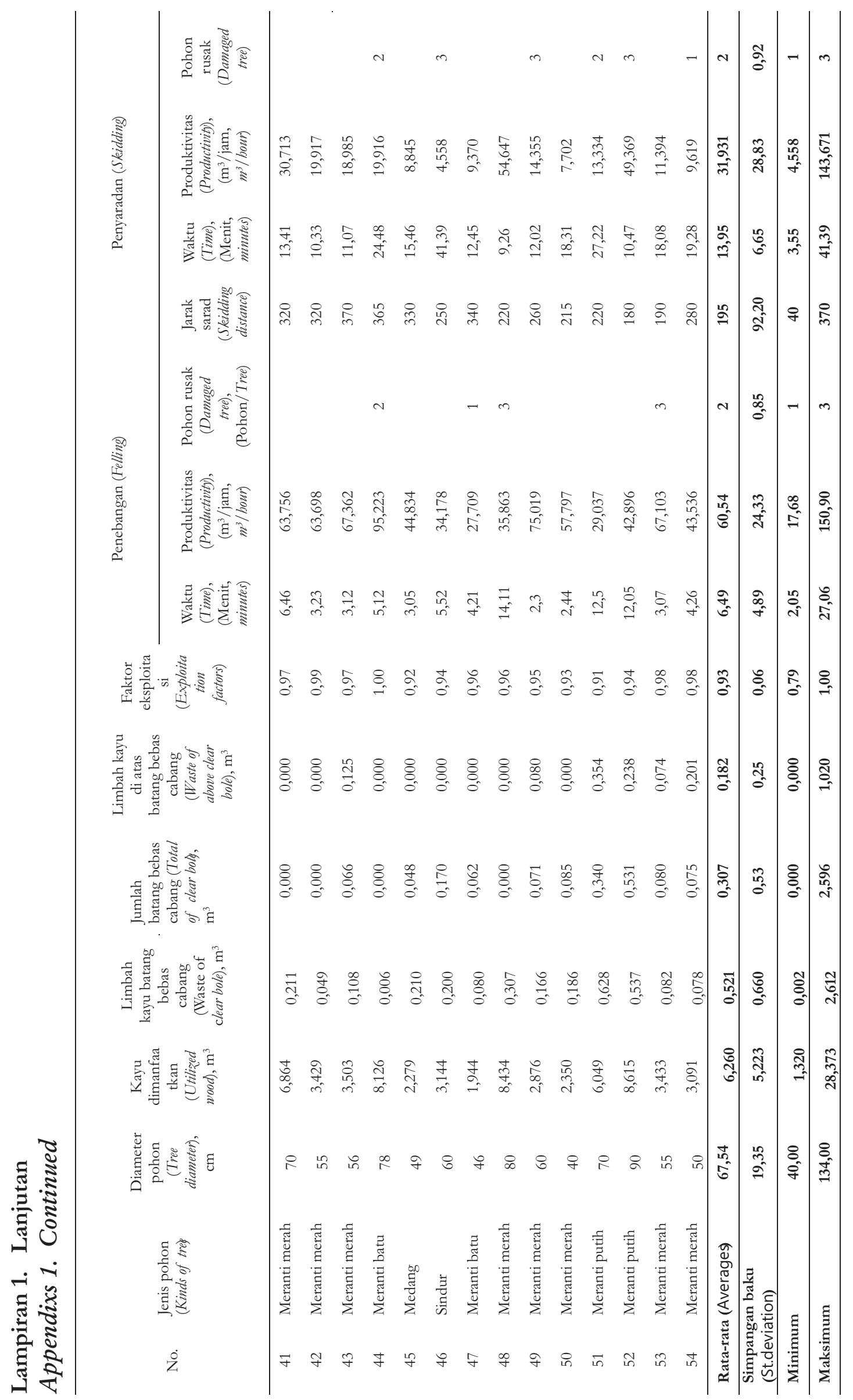




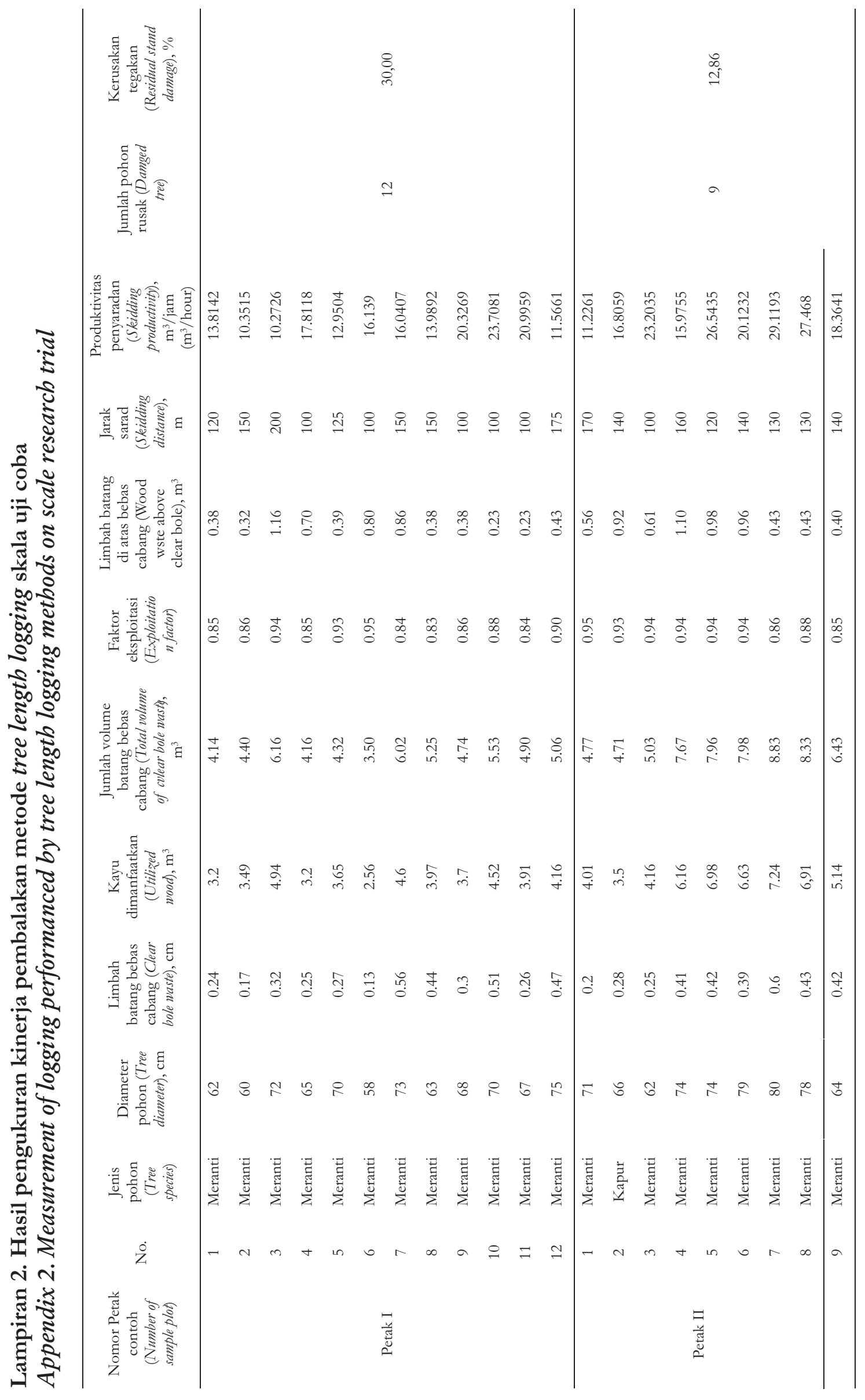




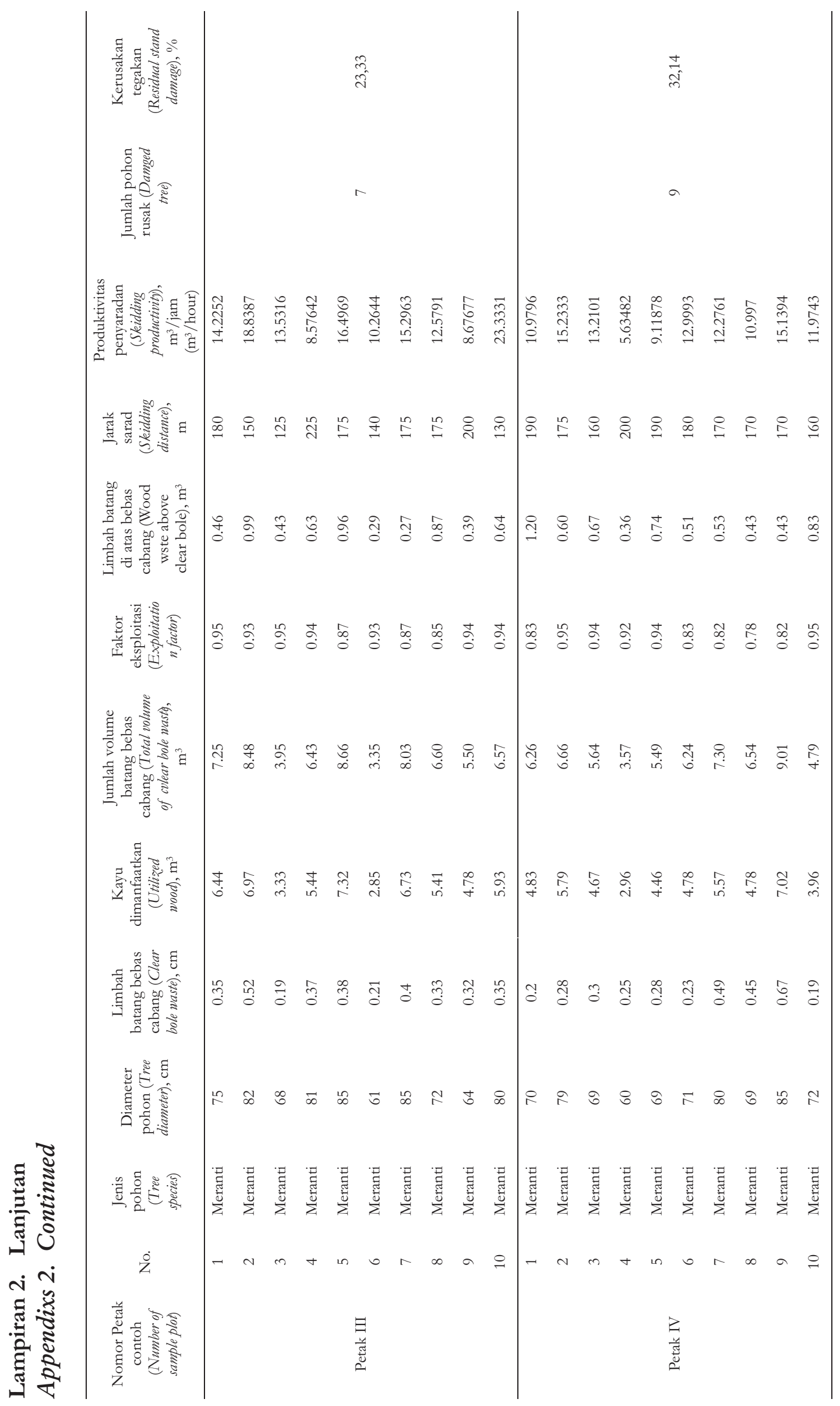




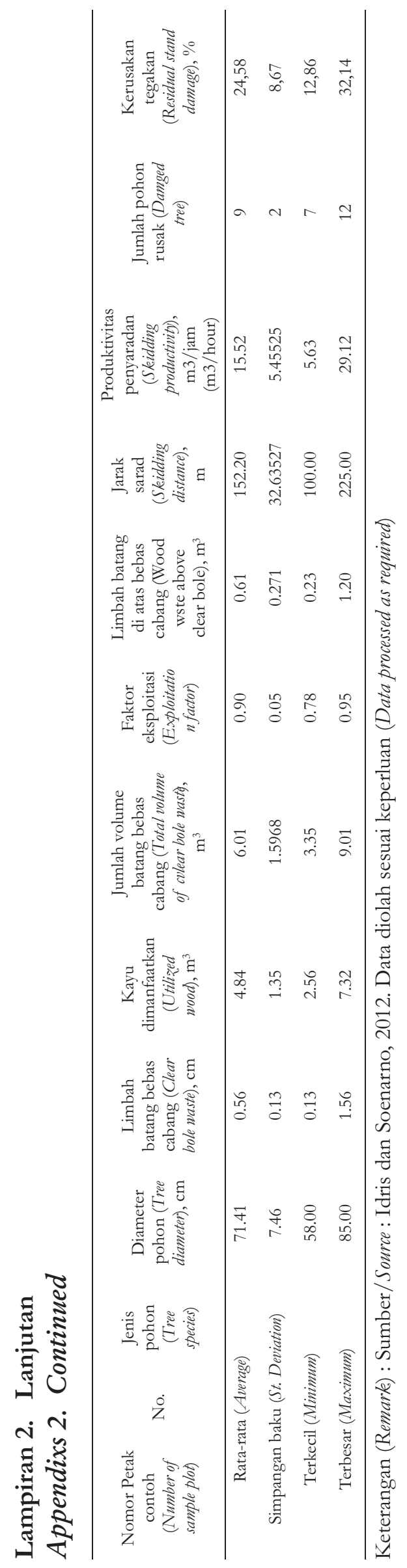

